\title{
Analisa Pengaruh Ask Content Terhadap Nilai Kalor Batubara Pada PT. Tribhakti Inspektama Samarinda
}

\author{
Irhamni Nuhardin*1 \\ ${ }^{1}$ Program Studi Teknik Kimia (Sekolah Tinggi Teknolgi Industri Bontang) \\ Email: 1irhamni.in@gmail.com
}

\begin{abstract}
Abstrak
Seiring dengan meningkatnya harga minyak dan gas bumi maka batubara sebagai bahan bakar alternatif sangat diharapkan dapat mengantisipasi kekurangan energi dengan meningkatkan pemanfaatannya untuk keperluan domestik, bahan bakar pembangkit tenaga listrik, dan lain sebagainya. Beberapa negara memiliki sistem klasifikasi batubara secara spesifik. Klasifikasi tersebut digunakan untuk menggolongkan batubara berdasarkan pemanfaatannya. Berdasarkan standar SNI 13-6011-1999 klasifikasi batubara di indonesia dibagi menjadi dua yaitu brown Coal dan hard coal. Umumnya, untuk mengetahui kualitas batubara dilakukan analisa kimia berupa analisis proksimat atau analisis ultimat. Tujuan dari penelitian ini adalah unuk mengetahui pengaruh kadar abu terhadap nilai kalor pada batubara. Indonesia sebelum mengekspor batubara ke negara-negara lain batubara terlebih dahulu diuji dan dianalisis untuk menentukan layak atau tidak untuk di berikan sesuai permintaan konsumenKadar abu merupakan kotoran yang tidak akan terbakar kandungannya berkisar 5\%-40\%. Oleh karena itu dilakukan analisis proximate untuk mengetahui pengaruh ash content. Metode yang digunakan dalam penelitian ini terdiri dari studi literatur, pengolahan sampel dan analisis data. Pengolahan sampel dengan cara menentukan Ash Content dan nilai kalor pada sampel batubara. Adapun cara menentukan Ash content yaitu dengan menimbang sampel batubara dengan berat tertentu kemudian dipanaskan hingga suhu $750^{\circ} \mathrm{C}$.dalam menentukan nilai kalor dampel batubara yang dianalisis menggunakan alat bomb calorimeter. Ash Content dan Nilai Kalor pada tujuh sampel yang di analisis yaitu sampel BB1 memiliki Ash Content 5,43 dengan nilai kalor 6007, sampel BB2 memiliki Ash Content 7,96 dengan nilai kalor 5752, sampel BB3 memiliki Ash Content 10,62 dengan nilai kalor 4780, sampel BB4 memiliki Ash Content 13,42 dengan nilai kalor 4712, sampel BB5 memiliki Ash Content 21,82 dengan nilai kalor 4154, sampel BB6 memiliki Ash Content 35.57 dengan nilai kalor 3218 dan sampel BB7 memiliki Ash Content 55,93 dengan nilai kalor 1921. Dapat disimpulkan bahwa nilai Ash Content sangat berpengaruh terhadap nilai kalor yang dihasilkan.
\end{abstract}

Kata kunci: Ash Content, Batubara, bomb calorimeter, brown coal, mineral matter, Proximate

\section{Analysis of the Influence of Ask Content on the Calorific Value of Coal at PT. Tribhakti Inspectama Samarinda}

\begin{abstract}
Along with the increase in oil and gas prices, coal as an alternative fuel is expected to anticipate energy shortages by increasing its use for domestic purposes, fuel for power generation, and so on. Some countries have specific coal classification systems. This classification is used to classify coal based on its utilization. Based on the standard SNI 13-6011-1999 coal classification in Indonesia is divided into two, namely brown coal and hard coal. Generally, to determine the quality of coal, chemical analysis is carried out in the form of proximate analysis or ultimate analysis. The purpose of this study was to determine the effect of ash content on the calorific value of coal. Indonesia before exporting coal to other countries, coal is first tested and analyzed to determine whether it is feasible or not to be supplied according to consumer demand. Ash content is an impurity that will not burn, its content ranges from 5\%-40\%. Therefore, a proximate analysis was carried out to determine the effect of ash content. The method used in this research consists of literature study, sample processing and data analysis. Sample processing by determining Ash Content and calorific value in coal samples. The method for determining Ash content is by weighing a sample of coal with a certain weight and then heating it to a temperature of $750^{\circ} \mathrm{C}$. In determining the calorific value of the coal dampel, the analysis uses a bomb calorimeter. Ash Content and Calorific Value in the seven samples analyzed, namely sample BB1 has an Ash Content of 5.43 with a heating value of 6007, sample BB2 has an Ash Content of 7.96 with a heating value of 5752, sample BB3 has an Ash Content of 10.62 with a heating value of 4780 , sample BB4 has Ash Content of 13.42 with calorific value of 4712, sample BB5 has Ash Content of 21.82 with calorific value of 4154, sample BB6 has Ash Content of 35.57 with calorific value of 3218 and sample BB7 has Ash Content of 55.93 with calorific value of 1921. It can be concluded that the value of Ash Content is very influential on the calorific value produced.
\end{abstract}

Keywords: Ash Content, Batubara, bomb calorimeter, brown coal, mineral matter, Proximate 


\section{PENDAHULUAN}

Batubara merupakan bahan galian yang menempati posisi sangat penting dalam pembangunan nasional. Seiring dengan meningkatnya harga minyak dan gas bumi maka batubara sebagai bahan bakar alternatif sangat diharapkan dapat mengantisipasi kekurangan energi dengan meningkatkan pemanfaatannya untuk keperluan domestik, bahan bakar pembangkit tenaga listrik, dan lain sebagainya.[1].

Beberapa negara memiliki sistem klasifikasi batubara secara spesifik. Klasifikasi tersebut digunakan untuk menggolongkan batubara berdasarkan pemanfaatannya. Berdasarkan standar SNI 13-6011-1999 klasifikasi batubara di indonesia dibagi menjadi dua yaitu brown Coal dan hard coal[8][9]. Umumnya, untuk mengetahui kualitas batubara dilakukan analisa kimia berupa analisis proksimat atau analisis ultimat[5]. Analisis proksimat dilakukan untuk menentukan jumlah air, zat terbang, karbon padat dan kadar abu. Sedangkan analisis ultimat untuk menentukan kandungan kimia pada batubara[6][7]. Pada penelitian sebelumnya yang pernah dilakukan terkait dengan hubungan antara total sulpur terhadap gross calorific value pada batubara menyatakan bahwa besarnya kandungan sulpur sangat mempengaruhi nilai kalor pada batubara sehingga perlu juga dilakukan analisa tentang bagaimana pengaruh nilai ash content terhadap nilai kalor pada batubara yang terdapat di sekitar wilayah Samarinda. Tujuan dari penelitian ini adalah unuk mengetahui pengaruh kadar abu terhadap nilai kalor pada batubara. Indonesia sebelum mengekspor batubara ke negara-negara lain batubara terlebih dahulu diuji dan dianalisis untuk menentukan layak atau tidak untuk di berikan sesuai permintaan konsumenKadar abu merupakan kotoran yang tidak akan terbakar kandungannya berkisar 5\%-40\%. Oleh karena itu dilakukan analisis proximate untuk mengetahui pengaruh ash content terhadap nilai kalor pada PT. Tribhakti Inspektama Samarinda.[2][3][4]

\section{METODE PENELITIAN}

Pengujian batubara pada PT. Tribhakti Inspektama Samarinda menggunakan metode yang telah digunakan secara internasional dan ASTM . Metode yang digunakan dalam penelitian ini terdiri dari studi literatur, pengolahan sampel dan analisis data. Studi literatur dilakukan dengan cara mengumpulkan dan mengkaji literatur yang bersumber dari jurnal, buku, laporan hasil penelitian terdahulu dan sebagainya yang dapat dijadikan referensi dalam penelitian ini. Pengelolaan data dilakukan dengan cara menganalisis kualitas batubara dengan parameter Ash Conten dan Nilai Kalor. Adapun cara menentukan Ash content yaitu sebagau berikut:

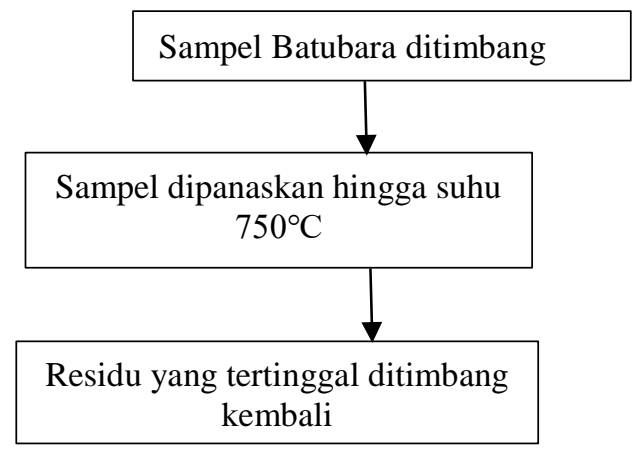

Nilai Ash Content yang dihasilkan kemudian dihitung dengan cara:

$$
\text { kadar ash content }=\frac{\text { bobot hilang }}{\text { bobot sampel }} \times 100 \%
$$

Setelah mengetahui kualitas sampel batubara yang digunakan maka dilakukan penentuan nilai kalor yang dianalisis dengan menggunakan alat bomb calorimeter Parr 6200, dimana hasil analisa nilai kalor sampel batubara tersimpan secara otomatis pada memori alat tersebut.

\section{HASIL DAN PEMBAHASAN}

Dari hasil penelitian dengan menggunakan analisa proximate di laboratorium maka di peroleh hasil analisa Ash Content pada batubara yang di ambil dari berbagai tempat sekitar wilayah Kalimantan Timur dan menentukan nilai kalor dengan menggunakan alat isoperibol Bomb Calorimeter Parr 6200 dapat dilihat pada Tabel 1.

Berdasarkan Tabel 1. Ash Content dan Nilai Kalor pada tujuh sampel batubara yang diberi ID sampel yaitu BB1 hingga BB7, maka di peroleh hasil analisa yaitu BB1 memiliki Ash Content 5,43 dengan nilai kalor 6007, sampel BB2 memiliki Ash Content 7,96 dengan nilai kalor 5752, sampel BB3 memiliki Ash Content 10,62 dengan 
nilai kalor 4780, sampel BB4 memiliki Ash Content 13,42 dengan nilai kalor 4712, sampel BB5 memiliki Ash Content 21,82 dengan nilai kalor 4154, sampel BB6 memiliki Ash Content 35.57 dengan nilai kalor 3218 dan sampel BB7 memiliki Ash Content 55,93 dengan nilai kalor 1921. maka dari ketujuh sampel tersebut diatas nilai Ash content yang diperoleh dari hasil analisis memiliki nilai yang cukup tinggi yaitu pada sampel BB5, BB6 dan BB7, berdasarkan hasil ash conten yang didapat, banyak mengandung mineral matter (ekstranius mineral matter dan inherent mineral matter) yang terkandung didalamnya yang tidak ikut terbakar, karena semakin banyak mineral matter didalamnya maka akan mempengaruhi jumlah kapasitas kalor yang dihasilkan. Sedangkan pada sampel BB1, BB2 BB3 dan BB4 memiliki nilai Ash Content yang cukup rendah dengan kandungan mineral matter yang tidak banyak sehingga tidak banyak mengurangi nilai kalor yang dihasilkan. Nilai Kalor yang dihasilkan berdasarkan Tabel 1 pada sampel BB1, BB2, BB3, BB4, BB5, BB6 dan BB7 dalam kondisi air dried basis (adb) yaitu 6007, 5772, 4780, 4712, 4154, 3218 dan 1921. Dari data tersebut terlihat bahwa sampel BB1 dan BB2 memiliki nilai kalor yang paling tinggi dibandingkan kelima sampel yang lain.

\begin{tabular}{cccc}
\multicolumn{4}{c}{ Tabel 1. Data Pengaruh Nilai Ash Conten Terhadap Nilai Kalor } \\
\hline No. & Sampel ID & Ash Content & Nilai Kalor \\
\hline 1 & BB1 & 5.43 & 6007 \\
2 & BB2 & 7.96 & 5772 \\
3 & BB3 & 10.62 & 4780 \\
4 & BB4 & 13.42 & 4712 \\
5 & BB5 & 21.82 & 4154 \\
6 & BB6 & 35.57 & 3218 \\
7 & BB7 & 55.93 & 1921 \\
\hline
\end{tabular}

Dari Tabel 1. terlihat bahwa terdapat pengaruh yang sangat signifikan dari nilai Ash Content dan nilai kalor dimana semakin tinggi Ash Content maka semakin kecil nilai kalor yang dihasilkan. Hal ini disebabkan karena pengaruh banyaknya mineral matter yang tidak ikut terbakar pada proses ashing sampel batubara, sehingga dapat mengganggu proses pembakaran dan nilai kalor yang dihasilkan menjadi kecil, karena semua energi (kalor) pada proses yang digunakan untuk pembakaran tidak cukup untuk membakar semua coal matter. Dalam penentua kualitas batubara yang dapat dikatakan kualitas baik atau rendah terdapat hal umum yang harus diketahui terlebih dahulu selain dari hasil pengujian laboratorium seperti kondisi awal batubara yang masih banyak mengandung air, kondisi batubara dalam air dried basis, pengujian sampel uji yang dikeringkan diudara terbuka kemudian dikonversikan perhitungannya untuk memenuhi kondisi kering, dried ash free dimana kondisi yang diasumsikan tidak ada sama sekali air maupun abu pada kondisi udara kering terbuka lalu dikonversi perhitungan untuk memenuhi kondisi air dan debu dried mineral matter free. Jadi nilai ash content dan nilai kalor belum cukup digunakan sebagai penentuan kualitas baik atau rendahnya batubara perlu juga melihat parameter lain yaitu menggunakan analisa proximate.

\section{KESIMPULAN}

Berdasarkan hasil penelitian maka diperoleh kesimpulan bahwa terdapat pengaruh yang signifikan antara Ash Content terhadap Nilai Kalor, dimana semakin tinggi nilai Ash Content maka nilai kalor semakin rendah dan sebaliknya semakin rendah nilai Ash Content maka semakin tinggi nilai kalor batubara.

\section{DAFTAR PUSTAKA}

[1] A. Andi, S. Widodo, A. Firmansyah, "Studi Penentuan Kandungan Sulfur (Sulfur Analysis) dalam Batubara Pada PT. Geoservices Samarinda Kalimantan Timur”, Jurnal Geomine, Vol. 2. 2015, pp. 68-71.

[2] M. Erwin, Anshariah, Agus A. B., "Analisis Proximat, Sulfur, dan Nilai Kalor dalam Penentuan Kualitas Batubara di Desa Pattappa Kecamatan Pujananting Kabupaten Barru Provinsi Sulawesi Selatan”, Jurnal Geomine, Vol. 6. No. 3. 2018, pp. 131-137.

[3] Sepfitra, “Analisis Proximat Kualitas Batubara Hasil Tambang Di Riau (Studi Kasus Logas, Selensen dan Pangkalan Lesung”, Jurnal Saintek STT Pekanbaru, Vol. 4. No. 1. 2016, pp. 18-26.

[4] N. Muhammad, Agung N., Windhu N., H. Hasan, "Hubungan Kandungan Total Sulpur Terhadap Cross Calorific Value pada Batubara PT. Carsurin Samarinda". Jurnal Teknologi Mineral FT UNMUL. Vol.7, No.1. 2019. PP 1-8 
[5] C. Bayu L., dkk., "Kajian Pengaruh Perubahan Kadar Air Total Batubara terhadap Perubahan Nilai Kalor dan Harga Batubara”, Indonesia Mining aand Energy Journal, Vol. 2 No.2. 2019, pp. 69-81.

[6] N. Zahratun, M. Oktavia, Desmawita, "Analisis Batubara di PIT dan Stockpile dengan Metoda Analisis Proksimat di PT. Surya Anugrah Sejahtera Kecamatan Rantau Pandan Kabupaten Bungo Provinsi Jambi". Vol.1, No.2. 2020. PP 1-5,

[7] Muchjidin, "Pengendalian Mutu Dalam Industri Batubara". Bandung. ITB. 2006

[8] Komariah, W. E., "Peningkatan Kualitas Batubara Indonesia Peringkat Rendah Melalui Penghilangan Moisture dengan Pemanasan Gelombang Mikro". Universitas Indonesia. 2012.

[9] Yusuf, S., "Analisa Batubara". Jakarta. UHAMKA.2011. 